\title{
IMMOBILIZATION OF CHROMIUM BY POULTRY MANURE AND GYPSUM IN SOIL AND REDUCING ITS UPTAKE BY SPINACH GROWN WITH TEXTILE EFFLUENT IRRIGATION
}

\author{
Hina Sattar', Muhammad Anwar-ul-Haq ${ }^{1, *}$, Hamaad Raza Ahmad ${ }^{1}$ and \\ Muhammad Jafar Jaskani
}

\author{
${ }^{1}$ Institute of Soil and Environmental Sciences, University of Agriculture, Faisalabad, Pakistan; ${ }^{2}$ Institute of \\ Horticultural Sciences, University of Agriculture, Faisalabad, Pakistan. \\ *Corresponding author's e.mail address: haq.gondal@ uaf.edu.pk
}

\begin{abstract}
Chromium $(\mathrm{Cr})$ is an ecological poison and its concentration is reaching to lethal intensities in soil and plants by irrigating the soil with raw industrial effluents, particularly in developing nations like Pakistan. Poultry manure and gypsum are recognized for their capability to immobilize heavy metals in soils for plant uptake and filtering to ground water. The current trial was conducted under controlled conditions to evaluate the viability of poultry manure (PM) and gypsum applications to mitigate $\mathrm{Cr}$ toxicity in spinach grown-up in soil watered with textile effluent. The trial was designed in a completely randomized design (CRD) with three repetitions. The treatments were: T1 (Control), T2 (Poultry Manure @ 0.5\%), T3 (Poultry Manure @ 1\%), T4 (Gypsum @ 0.3\%) and T5 (Gypsum @ 0.6\%). Chromium uptake by shoots and roots of spinach were enhanced in control plants where only textile effluent was applied. Chromium uptake in roots was higher than shoots. Application of poultry manure and gypsum reduced the $\mathrm{Cr}$ toxicity. The shoot length and dry weight of spinach was higher where PM was incorporated @ $1 \%$ as compared to gypsum and control. The extent of Cr toxicity mitigation by PM application@1\% was higher when compared with control. The outcomes of this investigation demonstrated that application of PM @ 1\% to the soil could be utilized as a viable approach for diminishing $\mathrm{Cr}$ concentration in spinach plants in $\mathrm{Cr}$ contaminated soils irrigated with untreated textile effluents.
\end{abstract}

Keywords: Chromium, immobilization, poultry manure, gypsum, textile effluent, spinach.

\section{INTRODUCTION}

Anthropogenic activities, for example, excavating, refining, water system utilizing wastewater, use of sewage sludge and atmospheric deposition have triggered serious heavy metal pollution around the globe (Wong et al., 2002). Soil is the main source of heavy metals as well as act as a sink for heavy metals. Collection of substantial metals in soils and their accumulation in the food chain is a potential risk to human wellbeing (Foucault et al., 2013; Bashir et al., 2018). The compounds of chromium $(\mathrm{Cr})$ are widely used in various industries and the effluent of these industries mostly released on agricultural soils. Metallurgical ventures, textile industries, chemical units and burning of coal and oil are the major sources of industrial effluent (Sharma et al., 2005). This industrial effluent usually discharged out into drains, from where it goes into water channels and used for irrigation of crops and turned into a major source of pollution for soils and plants with $\mathrm{Cr}$ and other heavy metals (Brar et al., 2000). Chromium is the risky metal released into natural surroundings by the industrial activities. Heavy metals are non-biodegradable unlike to other organic contaminants. Chromium exists in environment both in trivalent and hexavalent form. It is recognized that $\mathrm{Cr}$ (VI) is
500 times more harmful than the $\mathrm{Cr}$ (III). Industries like textile, paint and leather tanning mostly used hexavalent chromium. Abundance of chromium makes harm to liver, kidneys and nerves (Nagarajappa et al., 2017).

To lessen the plant available concentration of heavy metals in soil, distinctive remediation techniques are used during last decades and in this way limit the accumulation of heavy metals in the food chain (Clemente et al., 2012). Many amendments, for example, organic substances (Beesley et al., 2014), phosphate ores (Brown et al., 2004), lime (Geeblen et al., 2003), clay minerals (Sun et al., 2013; Liang et al., 2014) and industrial and agronomic by-products (Wang et al., 2014) have been created to bind heavy metals in soils. The plant available concentration is decreased by amendments application (Adams et al., 2004).

It is well known that organic amendments make stable complexes in soil and can bind the substantial quantities of metal (loid)s within these complexes (Shahid et al., 2014d; Sabir et al., 2015). Now a days fertilizer having low level of metals are utilized to bind metals in soils (Venegas et al., 2015). Khan et al. (2015) stated that the utilization of poultry manure (PM) was exceptionally viable in blocking plant uptake of metals. Organic amendments can increase the soil $\mathrm{pH}$ by anticipating sulfide oxidation and ultimately 
binds the heavy metals in soil (Walker et al., 2004). Moreover organic amendments can lessen metal bioavailability by expanding in surface charge by making stable associations with metal particles (Gadd, 2000).

Inorganic amendments have been found to lessen the bioavailability of metals because of formation of binding sites (Puschenreiter et al., 2005). Gypsum could enhance the physical and synthetic properties of soils for crops and limit the transport of dissolved natural carbon and metal complexes in soils and is considered as a cheaper source of calcium ( $\mathrm{Ca}$ ) and sulfur. The alkaline amendments could increase soil $\mathrm{pH}$ that supports the advancement of oxides, metal carbonates, precipitates, and associations, prompting diminished bioavailability (Abbas et al., 2017). In perspective of the lack of information on critical toxic ranges of $\mathrm{Cr}$ in green vegetables, especially spinach, the goal of this study was to research the adequacy of poultry manure and gypsum to diminish $\mathrm{Cr}$ take-up in spinach grown on textile effluent irrigated soil.

\section{MATERIALS AND METHODS}

Soil collection and textile effluent characteristics: A soil pot study was conducted in the wire house of institute of Soil and Environmental Sciences (ISES) Saline Agriculture Research Center (SARC), University of Agriculture, Faisalabad. Initially soil was assembled from soil science farm University of Agriculture, Faisalabad. Collected soil was stored in plastic containers for further analysis after airdrying, grinding and sieving through a $2 \mathrm{~mm}$ sieve. A sample of the prepared soil was analyzed for its different physicochemical properties, including $\mathrm{pH}$, electrical conductivity $\left(\mathrm{EC}_{\mathrm{e}}\right)$, organic matter $(\mathrm{OM})$, cation exchange capacity (CEC), water soluble cations and anions $\left(\mathrm{CO}_{3}{ }^{2-}\right.$, $\left.\mathrm{HCO}^{3-}, \mathrm{Cl}^{-}, \mathrm{Na}^{+}, \mathrm{Ca}^{2+}+\mathrm{Mg}^{2+}\right)$ and soil texture following Richards (1954). The initial physic-chemical properties of the experimental soil are given in Table 1.

Table 1. Initial physicochemical properties of the experimental soil.

\begin{tabular}{lcc}
\hline Parameters & Unit & Value \\
\hline Textural class & - & Sandy clay loam (SCL) \\
Sand & $\%$ & 49.10 \\
Silt & $"$ & 24.50 \\
Clay & $"$ & 26.40 \\
$\mathrm{pH}_{\mathrm{s}}$ & - & 8.16 \\
$\mathrm{EC}_{\mathrm{e}}$ & $\mathrm{dS} \mathrm{m}$ & 3.50 \\
$\mathrm{CO}_{3}{ }^{2-}$ & $\mathrm{mmol}_{\mathrm{c}} \mathrm{L}^{-1}$ & - \\
$\mathrm{HCO}_{3}{ }^{-}$ & $"$ & 4.70 \\
$\mathrm{Cl}^{-}$ & $"$ & 13.80 \\
$\mathrm{Ca}^{2+}+\mathrm{Mg}^{2+}$ & $"$ & 4.80 \\
$\mathrm{Na}^{+}$ & $"$ & 24.80 \\
$\mathrm{SAR}$ & $\left(\mathrm{mmol}_{\mathrm{c}} \mathrm{L}^{-1}\right)^{1 / 2}$ & 16.00 \\
$\mathrm{OM}$ & $\%$ & 0.82 \\
\hline
\end{tabular}

Soltanpour (1985) procedure was followed to determine the micronutrient in soil. The values are given in Table 2. Textile effluent collected from Dawood Textile Mill Faisalabad, Pakistan was used as irrigation water for growing spinach. The salient characteristics of the effluent are presented in Table 3.

Table 2. Total and available metals concentration in presowing soil.

\begin{tabular}{ccrc}
\hline Metal concentrations & Unit & Total & ${ }^{\text {a Available }}$ \\
\hline $\mathrm{Cr}$ & $\mathrm{mg} \mathrm{kg}^{-1}$ & 2.86 & 0.14 \\
$\mathrm{Zn}$ & $"$ & 36.16 & 3.37 \\
$\mathrm{Cu}$ & $"$ & 11.87 & 3.75 \\
$\mathrm{Mn}$ & $"$ & 44.87 & 4.01 \\
$\mathrm{Fe}$ & $"$ & 154.60 & 31.5 \\
\hline
\end{tabular}

${ }^{a}$ AB-DTPA extractable

Table 3. Characteristics of textile effluent used to irrigate plants.

\begin{tabular}{|c|c|c|c|}
\hline Parameters & Unit & Value & $\begin{array}{c}\text { Tolerable } \\
\text { limit }^{\text {a }}\end{array}$ \\
\hline $\mathrm{pH}$ & & 11 & $6-10$ \\
\hline $\mathrm{EC}$ & $\mathrm{dS} \mathrm{m} \mathrm{m}^{-1}$ & 10.45 & $<1.25$ \\
\hline Temperature & ${ }^{0} \mathrm{C}$ & 35 & Upto 40 \\
\hline $\begin{array}{l}\text { Total dissolved solids } \\
\text { (TDS) }\end{array}$ & $\mathrm{mg} \mathrm{L}^{-1}$ & 6614.67 & 3500 \\
\hline Dissolved oxygen (DO) & $\mathrm{mg} \mathrm{L}^{-1}$ & 2.70 & - \\
\hline $\begin{array}{l}\text { Biological oxygen demand } \\
(\mathrm{BOD})_{5}\end{array}$ & $\mathrm{mg} \mathrm{L}^{-1}$ & 1150 & 80 \\
\hline Chromium (Cr) & $\mathrm{mg} \mathrm{L}^{-1}$ & 1.72 & 1.0 \\
\hline Copper $(\mathrm{Cu})$ & $\mathrm{mg} \mathrm{L}^{-1}$ & 1.45 & 1.0 \\
\hline Cadmium $(\mathrm{Cd})$ & $\mathrm{mg} \mathrm{L}^{-1}$ & 0.14 & 0.1 \\
\hline Interpretations & \multicolumn{3}{|c|}{ Not suitable for irrigation } \\
\hline
\end{tabular}

${ }^{\mathrm{a}}$ Ayers and Westcot (1985).

Amendments: In this study the binding agents like poultry manure and gypsum were used. Poultry manure was taken from poultry farm of University of Agriculture, Faisalabad. Poultry manure was air dried and ground to pass through $2 \mathrm{~mm}$ sieve and was analyzed for various properties. Both $\mathrm{EC}$ and $\mathrm{pH}$ of poultry manure were determined with EC and $\mathrm{pH}$ meter. The samples were digested in di-acid $\left(\mathrm{HNO}_{3}: \mathrm{HClO}_{4}\right)$ mixture and was run on atomic absorption spectrometer to determine the concentration of micronutrients (Soltanpour, 1985). Solubility of gypsum $\left(\mathrm{CaSO}_{4} .2 \mathrm{H}_{2} \mathrm{O}\right)$ was $2.53 \mathrm{~g} \mathrm{~L}^{-1}$ in pure water and had $23.3 \%$ calcium $(\mathrm{Ca})$ contents. $\mathrm{pH}$ and $\mathrm{EC}$ of poultry manure was 6.99 and $7.29 \mathrm{dS} \mathrm{\textrm {m } ^ { - 1 }}$, respectively. Copper, Zinc and Manganese concentration in poultry manure was $407 \mathrm{mg} \mathrm{kg}^{-}$ 1, $794 \mathrm{mg} \mathrm{kg}^{-1} 596 \mathrm{mg} \mathrm{kg}^{-1}$, respectively.

Experimental design: The experiment was arranged in a completely randomized design (CRD) with three replications. The treatment plan was $\mathrm{T}_{1}$ (Control), $\mathrm{T}_{2}$ (Poultry Manure @ 0.5\%), $\mathrm{T}_{3}$ (Poultry Manure @ 1\%), $\mathrm{T}_{4}$ 
(Gypsum @ 0.3\%) and $\mathrm{T}_{5}$ (Gypsum @ 0.6\%). Twelve kg of soil was filled in each pot. The amendments were thoroughly mixed in soil at the time of pot filling. Basal dose of $35 \mathrm{mg}$ $\mathrm{N}$ and $5.4 \mathrm{mg} \mathrm{P}$ per $\mathrm{kg}$ of soil was applied in each pot and almost fifteen seeds of spinach were sown in each pot. After germination five plants were maintained in each pot. The plants were watered with textile effluent collected from Dawood Textile Mill Faisalabad, Pakistan. Total eleven irrigations, each of $600 \mathrm{~mL}$ were applied to spinach plants throughout the study period.

Determination of gas exchange and physiological parameters: Gas exchange parameters i.e. rate of photosynthesis, rate of transpiration and stomatal conductance was monitored and recorded by IRGA (InfraRed Gas Analyzer LCA4). Chlorophyll contents were recorded by using chlorophyll meter. Physiological parameters i.e. relative water contents (RWC), leaf area and membrane stability index (MSI) were also determined by collecting the fresh leaves before final harvesting.

Determination of growth parameters: First cutting of spinach was taken after 45 days of sowing and second cutting was taken after 90 days of first cutting. Plant height and fresh weights of shoots and roots were measured at the time of $2^{\text {nd }}$ harvesting after 90 days. Plants were isolated into roots and shoots, and fresh weights were recorded promptly after harvest. The length of shoots and roots were also recorded at the time of harvesting. Subsequently, taking the fresh weight of shoots and roots the mockups were dried out in air and then kept in the oven at $70^{\circ} \mathrm{C}$ for $72 \mathrm{~h}$ and till steady dry weights were acquired.

Determination of chromium (Cr): The collected samples of shoots and roots were digested using diacid mixture $\left(\mathrm{HNO}_{3}: \mathrm{HClO}_{4}\right)$ and filtered through filter paper and then fed to atomic absorption spectrometer for the determination of
$\mathrm{Cr}$ metal following calibration of the equipment with standard solutions of $\mathrm{Cr}$ metal and readings were recorded.

Statistical analysis: The results were analyzed using software Statistics 8.1. Results were equated using a general linear model. The data was analyzed statistically following Analysis of Variance technique (ANOVA) and means were separated by LSD test.

\section{RESULTS}

Growth parameters: The effect of poultry manure and gypsum was observed on growth parameters of spinach. The results showed that amendments significantly $(\mathrm{P}<0.05)$ increased the growth of spinach as compared to control plants where no amendment was applied (Table 4). A considerable increase in shoot length was recorded in all treatments as compared to control. The highest increase in shoot length $(50 \%)$ was recorded with poultry manure application@1\% ( $\left.\mathrm{T}_{3}\right)$. While the lowest increase $(31 \%)$ in shoot length was observed in control $\left(\mathrm{T}_{1}\right)$. Overall, shoot length was improved in the following arrangement $T_{3}>T_{5}>$ $\mathrm{T}_{4}>\mathrm{T}_{2}>\mathrm{T}_{1}$ revealed better shoot length as compared to other treatments. Similarly, substantial $(\mathrm{P}<0.05)$ increase in number of leaves pot ${ }^{-1}$ of spinach was observed by applying amendments except control plants (Table 4). The maximum increase in number of leaves pot $^{-1}$ of spinach was recorded with poultry manure application @ 1\% $\left(\mathrm{T}_{3}\right)$ that was $20 \%$ higher as compared to control plants without amendments where increase was only $8 \%$ (Table 4 ).

Amendments also showed significant $(P<0.05)$ effect on shoot fresh and dry weights of spinach plants as compared to control (Table 4). Maximum shoot fresh weight (57\%) of spinach after 90 days was obtained with the soil application of poultry manure @ 1\% ( $\left.\mathrm{T}_{3}\right)$, whereas the control $\left(\mathrm{T}_{1}\right)$

Table 4. Shoot and root length $(\mathrm{cm})$, number of leaves $\left(\right.$ pot $\left.^{-1}\right)$, shoot and root fresh and dry weights $\left(\mathrm{g} \mathrm{pot}^{-1}\right)$ of $^{-}$ spinach grown under different treatments.

\begin{tabular}{|c|c|c|c|c|c|c|c|c|c|c|c|}
\hline \multirow[t]{2}{*}{ Treatments } & \multicolumn{2}{|c|}{ Shoot length (cm) } & \multicolumn{2}{|c|}{$\begin{array}{c}\begin{array}{c}\text { Number of leaves } \\
\left(\text { pot }^{-1}\right)\end{array} \\
\end{array}$} & \multicolumn{2}{|c|}{ Shoot Fresh Weight (g) } & \multicolumn{2}{|c|}{ Shoot Dry Weight (g) } & \multirow{2}{*}{$\begin{array}{c}\text { Root } \\
\text { Length } \\
\text { (cm) }\end{array}$} & \multirow[t]{2}{*}{$\begin{array}{l}\text { Root fresh } \\
\text { weight (g) }\end{array}$} & \multirow[t]{2}{*}{$\begin{array}{c}\text { Root dry } \\
\text { weight (g) }\end{array}$} \\
\hline & $\begin{array}{c}\text { After } 45 \\
\text { days }\end{array}$ & $\begin{array}{c}\text { After } 90 \\
\text { days }\end{array}$ & $\begin{array}{c}\text { After } 45 \\
\text { days }\end{array}$ & $\begin{array}{c}\text { After } 90 \\
\text { days }\end{array}$ & $\begin{array}{c}\text { After } 45 \\
\text { days }\end{array}$ & $\begin{array}{c}\text { After } 90 \\
\text { days }\end{array}$ & $\begin{array}{c}\text { After } 45 \\
\text { days }\end{array}$ & $\begin{array}{c}\text { After } 90 \\
\text { days }\end{array}$ & & & \\
\hline Control & $\begin{array}{c}15 \pm 1.20 \\
b\end{array}$ & $\begin{array}{c}22 \pm 2.03 \\
(31) \mathrm{c}\end{array}$ & $\begin{array}{c}41 \pm 1.02 \\
\mathrm{c}\end{array}$ & $\begin{array}{c}45 \pm 1.26(8) \\
d\end{array}$ & $\begin{array}{c}45.67 \pm 0.67 \\
\mathrm{c}\end{array}$ & $\begin{array}{c}80.67 \pm 2.60 \\
(43) \mathrm{c}\end{array}$ & $\begin{array}{c}4.49 \pm 0.07 \\
\mathrm{~d}\end{array}$ & $\begin{array}{l}5.05 \pm 0.67 \\
(11) \mathrm{c}\end{array}$ & $\begin{array}{c}18.33 \pm 1.20 \\
b\end{array}$ & $\begin{array}{c}8.00 \pm 0.58 \\
\mathrm{c}\end{array}$ & $\begin{array}{c}1.05 \pm 0.05 \\
\mathrm{c}\end{array}$ \\
\hline $\begin{array}{l}\text { Poultry } \\
\text { manure@0.5\% }\end{array}$ & $\begin{array}{c}21 \pm 0.33 \\
\mathrm{ab}\end{array}$ & $\begin{array}{c}35 \pm 0.88 \\
(40) \mathrm{b}\end{array}$ & $\begin{array}{c}59 \pm 2.65 \\
\mathrm{ab}\end{array}$ & $\begin{array}{c}72 \pm 1.73 \\
(18) b\end{array}$ & $\begin{array}{c}61.33 \pm 1.76 \\
b\end{array}$ & $\begin{array}{c}117.67 \pm 5.36 \\
(47) \mathrm{b}\end{array}$ & $\begin{array}{c}6.21 \pm 0.14 \\
c\end{array}$ & $\begin{array}{l}7.53 \pm 0.81 \\
(17) \mathrm{bc}\end{array}$ & $\begin{array}{c}22.33 \pm 2.19 \\
(17.9) \mathrm{ab}\end{array}$ & $\begin{array}{c}12.67 \pm 0.33 \\
(36.8) b\end{array}$ & $\begin{array}{c}1.72 \pm 0.13 \\
(38.9) \mathrm{ab}\end{array}$ \\
\hline $\begin{array}{l}\text { Poultry } \\
\text { manure@1\% }\end{array}$ & $\begin{array}{c}23 \pm 0.88 \\
\mathrm{a}\end{array}$ & $\begin{array}{c}46 \pm 1.45 \\
(50) \mathrm{a}\end{array}$ & $\begin{array}{c}65 \pm 1.73 \\
a\end{array}$ & $\begin{array}{c}82 \pm 3.38 \\
(20) \mathrm{a}\end{array}$ & $\begin{array}{c}70.00 \pm 0.88 \\
a\end{array}$ & $\begin{array}{c}163.00 \pm 10.8 \\
2(57) \mathrm{a}\end{array}$ & $\begin{array}{c}9.19 \pm 0.34 \\
\mathrm{a}\end{array}$ & $\begin{array}{c}15.34 \pm 0.71 \\
(40) \mathrm{a}\end{array}$ & $\begin{array}{c}26.00 \pm 1.53 \\
(29.5) \mathrm{a}\end{array}$ & $\begin{array}{c}18.67 \pm 1.76 \\
(57.1) \mathrm{a}\end{array}$ & $\begin{array}{c}2.08 \pm 0.03 \\
(49.5) \mathrm{a}\end{array}$ \\
\hline $\begin{array}{l}\text { Gypsum@0.3 } \\
\%\end{array}$ & $\begin{array}{c}21 \pm 0.58 \\
\mathrm{ab}\end{array}$ & $\begin{array}{c}36 \pm 2.33 \\
(41) b\end{array}$ & $\begin{array}{c}49 \pm 2.04 \\
\text { bc }\end{array}$ & $\begin{array}{c}56 \pm 1.20 \\
(12) \mathrm{c}\end{array}$ & $\begin{array}{c}52.33 \pm 1.76 \\
\text { c }\end{array}$ & $\begin{array}{c}108.67 \pm 10.1 \\
7(51) b\end{array}$ & $\begin{array}{c}5.94 \pm 0.07 \\
\mathrm{c}\end{array}$ & $\begin{array}{c}6.07 \pm 0.65 \\
(15) \mathrm{c}\end{array}$ & $\begin{array}{c}19.00 \pm 1.00 \\
(3.52) \mathrm{b}\end{array}$ & $\begin{array}{c}11.67 \pm 1.86 \\
(31.4) b c\end{array}$ & $\begin{array}{c}1.43 \pm 0.02 \\
(26.5) \mathrm{bc}\end{array}$ \\
\hline \multirow[t]{2}{*}{$\begin{array}{l}\text { Gypsum@0.6 } \\
\%\end{array}$} & $\begin{array}{c}21 \pm 1.20 \\
\mathrm{ab}\end{array}$ & $\begin{array}{c}38 \pm 1.15 \\
(44) b\end{array}$ & $\begin{array}{c}49 \pm 2.85 \\
\text { bc }\end{array}$ & $\begin{array}{c}55 \pm 1.15 \\
(10) \mathrm{c}\end{array}$ & $\begin{array}{c}51.33 \pm 2.91 \\
\mathrm{c}\end{array}$ & $\begin{array}{c}112.33 \pm 4.10 \\
(54) \mathrm{b} \\
\text { LSD values }\end{array}$ & $\begin{array}{c}6.35 \pm 0.60 \\
b\end{array}$ & $\begin{array}{c}9.85 \pm 0.97 \\
(35) \mathrm{b}\end{array}$ & $\begin{array}{c}21.33 \pm 1.67 \\
(14.1) \mathrm{ab}\end{array}$ & $\begin{array}{c}14.67 \pm 1.45 \\
(45.4) \mathrm{ab}\end{array}$ & $\begin{array}{c}1.49 \pm 0.27 \\
(29.5) \mathrm{b}\end{array}$ \\
\hline & 2.62 & 5.23 & 3.21 & 5.56 & 7.36 & 23.41 & 0.54 & 2.42 & 4.94 & 4.25 & 0.43 \\
\hline
\end{tabular}

Each value is average of three replicates \pm S.E, and values in parenthesis mentioned with shoot length, number of leaves, shoot fresh and shoot dry weights are the percent increase with respect to days, while the values in parenthesis mentioned with root length, root fresh and dry weights are the percent increase with respect to control, the significant difference between treatments was determined by LSD test $(\mathrm{P} \leq 0.05)$ 
showed minimum rise $(43 \%)$. Overall, increasing trend of shoot fresh weight of spinach was observed as $\mathrm{T}_{3}>\mathrm{T}_{5}>\mathrm{T}_{4}>$ $\mathrm{T}_{2}>\mathrm{T}_{1}$. Following the same trend, application of poultry manure @ 1\% $\left(\mathrm{T}_{3}\right)$ showed the highest progress in shoot dry weight of spinach $(40 \%)$ with respect to days as compared to control $\left(\mathrm{T}_{1}\right)$ where increase was $(11 \%)$. The increasing trend for all the treatments was $T_{3}>T_{5}>T_{2}>T_{4}>T_{1}$.

Application of amendments also increased the root length over control (Table 4). Maximum increase in root length (29.5\%) was recorded with the application of poultry manure @ $1 \%\left(\mathrm{~T}_{3}\right)$ over control $\left(\mathrm{T}_{1}\right)$. Whereas the increase was minimum (3.5\%) with the application of gypsum @0.3\% with respect to control. The overall increasing trend in root length of spinach was noted as $T_{3}>T_{2}>T_{5}>T_{4}>T_{1}$. The root fresh and dry weights were also enhanced with the application of poultry manure @ 1\% as compared to control (Table 4). The maximum increase in root fresh weight was $(57.1 \%)$ while maximum increase in root dry weight was (49.5\%) over control. The overall increasing trend for root fresh and dry weights were noted as $\mathrm{T}_{3}>\mathrm{T}_{5}>\mathrm{T}_{2}>\mathrm{T}_{4}>\mathrm{T}_{1}$ and $\mathrm{T}_{3}>\mathrm{T}_{2}>\mathrm{T}_{5}>\mathrm{T}_{4}>\mathrm{T}_{1}$ respectively.

Gas exchange parameters: The amendments also showed positive response over gas exchange parameters of spinach plants. The maximum value of transpiration rate and stomatal conductance was noted in poultry manure @ $1 \%$ treated plants and control plants showed lowest value of these parameters (Fig. 1). Similarly, the mean maximum value of photosynthetic rate was also recorded in poultry manure (@1\%) applied plants. Hence it was noted that application of poultry manure @ 1\% considerably enhanced the transpiration and photosynthetic rate and stomatal conductance in contaminated soil (Fig. 1).

Physiological parameters: All treatments described a remarkable ( $\mathrm{P}<0.05)$ increment in chlorophyll substance of spinach plants than control (Table 5). Poultry manure @ 1\% (T3) showed maximum improvement in chlorophyll contents
(66.7\%) with respect to control. The amendments also improved the relative water contents in spinach plants as compared to control (Table 5). The most extreme increment in relative water contents of spinach was found in $\mathrm{T} 3$ treatment. The spinach plants also showed a noteworthy $(\mathrm{P}<$ 0.05 ) increment in membrane stability index (MSI) by applying amendments. Poultry manure @ 1\% (T3) showed most elevated increment (44\%) in MSI than control. Osmotic potential of spinach was also enhanced by using all amendments than control (Table 5). The highest increase $(62.8 \%)$ was seen in T3 treatment with respect to control. Overall, the expansion in osmotic potential was noted with the expanding arrangement $\mathrm{T} 3>\mathrm{T} 5>\mathrm{T} 2>\mathrm{T} 4>\mathrm{T} 1$.

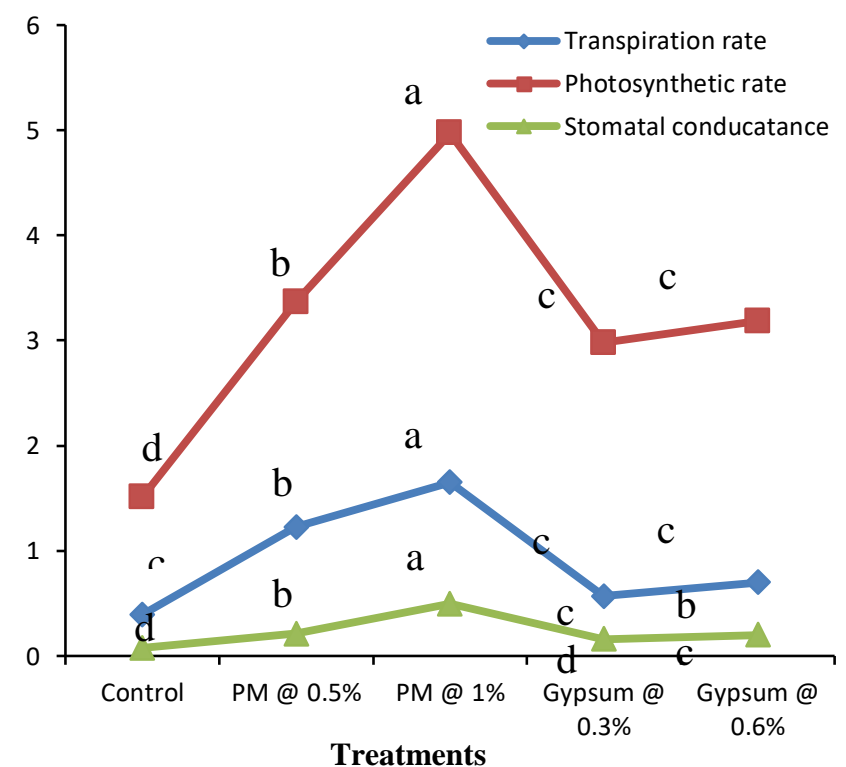

Figure 1.Photosynthetic rate (A) $\left(\mu \mathrm{mol} \mathrm{CO}_{2} \mathrm{~m}^{-2} \mathrm{~s}^{-1}\right)$, transpiration rate $(\mathrm{E})\left(\mathrm{mmol} \mathrm{H}_{2} \mathrm{O} \mathrm{m}^{-2} \mathrm{~s}^{-1}\right)$ and

Table 5. Chlorophyll contents (SPAD values), relative water contents (\%), membrane stability index (\%) and osmotic potential (\%) of spinach grown under different treatments.

\begin{tabular}{lcccc}
\hline Treatments & $\begin{array}{c}\text { Chlorophyll contents } \\
\text { (SPAD values) }\end{array}$ & $\begin{array}{c}\text { Relative water } \\
\text { contents (\%) }\end{array}$ & $\begin{array}{c}\text { Membrane stability } \\
\text { index (\%) }\end{array}$ & $\begin{array}{c}\text { Osmotic potential } \\
(\boldsymbol{\%})\end{array}$ \\
\hline Control & $22.93 \pm 0.68 \mathrm{c}$ & $54.66 \pm 2.40 \mathrm{~d}$ & $47.67 \pm 1.45 \mathrm{~d}$ & $158.33 \pm 3.53 \mathrm{e}$ \\
Poultry manure@0.5\% & $56.70 \pm 3.95$ & $85.27 \pm 2.73$ & $73.67 \pm 2.60$ & $326.67 \pm 4.41$ \\
& $(59.5) \mathrm{b}$ & $(35.8) \mathrm{bc}$ & $(35.2) \mathrm{b}$ & $(51.5) \mathrm{c}$ \\
Poultry manure@ $1 \%$ & $68.93 \pm 1.46$ & $97.68 \pm 1.45$ & $84.67 \pm 1.76$ & $426.67 \pm 3.06$ \\
& $(66.7) \mathrm{a}$ & $(44) \mathrm{a}$ & $(43.6) \mathrm{a}$ & $(62.8) \mathrm{a}$ \\
Gypsum@0.3\% & $43.40 \pm 1.65$ & $79.96 \pm 4.17$ & $65.00 \pm 1.15$ & $279.00 \pm 3.46$ \\
& $(47.1) \mathrm{bc}$ & $(31.6) \mathrm{c}$ & $(26.6) \mathrm{c}$ & $(43.2) \mathrm{d}$ \\
Gypsum@00.6\% & $55.80 \pm 0.30$ & $89.26 \pm 1.69$ & $75.33 \pm 2.03$ & $384.00 \pm 2.08$ \\
& $(58.9) \mathrm{b}$ & $(38.7) \mathrm{b}$ & $(36.7) \mathrm{b}$ & $(58.7) \mathrm{b}$ \\
& & & & \\
& 9.87 & 8.40 & 5.88 & 9.93 \\
\hline
\end{tabular}

Each value is an average of three replications \pm S.E, and values in parenthesis are the percent increase with respect to control, the significant difference between treatments was determined by LSD test $(\mathrm{P} \leq 0.05)$ 
Chromium uptake by spinach

Table 6. Chromium concentration $\left(\mathrm{mg} \mathrm{kg}^{-1}\right)$ in shoots and roots of spinach grown under different treatments.

\begin{tabular}{|c|c|c|c|}
\hline \multirow[t]{2}{*}{ Treatments } & \multicolumn{2}{|c|}{ Cr in shoots $\left(\mathrm{mg} \mathrm{kg}^{-1}\right)$} & \multirow[t]{2}{*}{$\mathrm{Cr}$ in roots $\left(\mathrm{mg} \mathrm{kg}^{-1}\right)$} \\
\hline & After 45 days & After 90 days & \\
\hline Control & $0.22 \pm 0.02 \mathrm{a}$ & $0.14 \pm 0.01(36) \mathrm{a}$ & $0.37 \pm 0.01 \mathrm{a}$ \\
\hline Poultry manure@0.5\% & $0.17 \pm 0.01 \mathrm{~cd}$ & $0.08 \pm 0.01(52) \mathrm{c}$ & $0.21 \pm 0.01(43) b$ \\
\hline Poultry manure@1\% & $0.14 \pm 0.01 \mathrm{~d}$ & $0.04 \pm 0.01(71) \mathrm{d}$ & $0.13 \pm 0.01(64) \mathrm{c}$ \\
\hline Gypsum@0.3\% & $0.20 \pm 0.01 \mathrm{ab}$ & $0.11 \pm 0.01(45) \mathrm{b}$ & $0.24 \pm 0.03(35) b$ \\
\hline Gypsum@0.6\% & $0.19 \pm 0.01 \mathrm{bc}$ & $\begin{array}{l}0.10 \pm 0.01(47) \mathrm{bc} \\
\underline{L S D} \text { values }\end{array}$ & $0.21 \pm 0.01(43) b$ \\
\hline & 0.03 & 0.02 & 0.05 \\
\hline
\end{tabular}

Each value is average of three replications \pm S.E, and values in parenthesis mentioned with $\mathrm{Cr}$ in shoots are the percent decrease with respect to days, while the values in parenthesis mentioned with $\mathrm{Cr}$ in roots are the percent decrease with respect to control, the significant difference between treatments was determined by LSD test $(\mathrm{P} \leq 0.05)$

stomatal conductance (gs) $\left(\mathrm{mol} \mathbf{m}^{-2} \mathbf{s}^{-1}\right)$ of spinach grown under different treatments.

Chromium concentration in plants: Uptake of chromium was considerably changed by the use of organic and inorganic amendments in contaminated soil (Table 6). The amendments showed a substantial $(\mathrm{P}<0.05)$ reduction in shoot $\mathrm{Cr}$ concentrations than control (Table 6). Poultry manure@1\% revealed maximum reduction (71\%) after 90 days in uptake of chromium in shoots of spinach plants compared to control plants where reduction was $36 \%$ after 90 days. In spinach shoots decrease in total $\mathrm{Cr}$ was noted with the ascending arrangement as $T_{3}>T_{2}>T_{5}>T_{4}>T_{1}$. Likewise, a substantial $(\mathrm{P}<0.05)$ reduction in spinach roots $\mathrm{Cr}$ contents was noted by incorporating the amendments in soil than respective control plants (Table 6). Poultry manure @ 1\% highly decreased (64\%) the $\mathrm{Cr}$ concentration in spinach $\left(T_{3}\right)$ than the control. Overall, increasing order was noted as $T_{3}>T_{2}=T_{5}>T_{4}>T_{1}($ Table 6$)$.

\section{DISCUSSION}

Chromium (VI) is the type of Cr normally found at polluted sites and its harmful levels are common in soils applied with sewage sludge. Soil organic matter proved to be effective in reducing Cr (III) from soil (Wuana et al., 2011). Chromium (Cr) is required for starch and lipid digestion, usage of amino acids and as pigments for paints, paper, concrete and rubber, metal plating to reduce corrosion, leather tanning and textile shading colors (Ahmet et al., 2010). Chromium is collected by plants and its accumulation is biomagnified at various trophic levels through food chain (Rai et al., 2002). Chromium can also react with various metabolic processes and causes danger to the plants, as lessened development and phytomass, chlorosis, inhibit photosynthesis, stunting growth and ultimately death of the plants. Moreover, plants emerging on chromium contaminated soil face a potential hazard from reactive oxygen species (ROS). Their presence makes oxidative harm to biomolecules, for example, lipids and proteins (Vajpayee et al., 2002).
In this investigation it was examined that control plants exhibited hindered development and yield when compared with other amendments. This was because of the reason that $\mathrm{Cr}$ danger timid the spinach growth. Moreover, its hazard lessened the plant biomass and promoted the take-up of $\mathrm{Cr}$ to aerial plant parts. In the present examination it was noted that control plants showed decreased growth due to $\mathrm{Cr}$ toxicity. Liu et al. (2004) found that toxicity of heavy metals cause reduction in the length of corn seedlings. The cause behind the damaging impact of heavy metal on plant development may be because of physical and chemical reactions between heavy metals and soil which changed the soil physical properties and eventually influenced the soil productivity. Chang and $\mathrm{Wu}$ (2005) found that the plant's capacity to assimilate phosphorus diminishes which influenced the plant development due to heavy metal contamination that can bind the phosphorous in soil.

The results of different experiments revealed the metal binding proficiency of various organic and inorganic amendments (Qayyum et al., 2017; Yang et al., 2017). Our current investigation indicated that the use of poultry manure and gypsum showed substantial outcomes for enhancing the development of spinach than control plants. The beneficial outcome of organic manure on shoot length could be because of the incorporation of organic compost that increases the richness status of the soil. The physicochemical properties of soil improve by the decomposition of manure. This could have prompted its high vegetative development (Awodun, 2007).

Spinach plants established on poultry manure performed better as far as the tallness of the plant than gypsum. This demonstrates that poultry manure was promptly accessible to plant roots in the best form for easy absorption, henceforth there was a lift in the morphological development of the plant. The consequences of this examination additionally authenticated the conclusion of Ajari et al. (2003) in vegetable growth in which they detailed that natural compost; particularly chicken manure could enhance the shoot length when compared with other manures. Chicken manure delivered primarily taller plants at 5,10 , and $15 \mathrm{t} / \mathrm{ha}$ 
than the control at all the examining dates. This finding is as a team with that of Okalebo et al. (2001) who reported that the consolidated utilization of maize with poultry manure gave a noteworthy increment in plant tallness.

The outcomes of the study demonstrated that poultry manure treated plants had most remarkable number of leaves pot $^{-1}$ than gypsum treated plants. The expansion in number of leaf per plant with organic manure incorporation stressed its significance throughout the somatic development of plants (Fagwalawa and Yahaya, 2016).

In this study it was shown that poultry manure expanded the shoot fresh and dry weights of spinach. The expansion in fresh weight of spinach because of poultry manure application could be endorsed due to high solubility of released plant nutrients which prompts the supplement status of the soil. The outcomes obtained were supported with the discoveries of Sanwal et al. (2007) in okra and Premsekhar and Rajashree (2009) (A. esculentus) in turmeric (Curcuma longa) in which they stated that organic manure application give higher yield to crops that could be credited to enhanced physical and organic properties of the soil bringing about good provision of supplements to the plants. Most likely in light of the fact that as the manures expanded the water holding capacity of the soil and also increased the release of subsequent supplement in soil. Substitution of synthetic compost by natural fertilizers has been accounted to upgrade soil biological activity; productivity and the rate of microbial substrate utilize (Worthington, 2001). Recently higher yields of lettuce were accounted by using chicken manure and ultimately bounce back inorganic manure (Masarirambi et $a l ., 2010)$. Expanded vegetable yield with the utilization of manure has also been accounted for (Ogunlela et al., 2005).

In this examination it was noted that use of poultry manure enhanced the physiological parameters of spinach plants. The control plants showed minimum increase in physiological parameters where no amendment was applied. This may be because of reason that $\mathrm{Cr}$ toxicity poses adverse impacts on the chloroplast and bringing down of other physical procedures that are compulsory for typical development and improvement of plants (Rizwan et al., 2016; Rehman et al., 2017). Usually, the most noteworthy increment in all the physical constraints was observed in T3 which may be because of strong part of high rate of poultry manure application for bringing down the damages of $\mathrm{Cr}$ destructiveness and establishment of appropriate nutrients (Abbas et al., 2017).

Conclusion: By comparing the effects of gypsum and poultry manure on yield and growth of spinach and reducing $\mathrm{Cr}$ uptake in shoots and roots of spinach plants, it is concluded that poultry manure (PM) @ 1\% is effective in reducing the phytoavailability of $\mathrm{Cr}$ in spinach plants. It was additionally presumed that in calcareous soil, poultry manure can be utilized to diminish the phytotoxicity of heavy metals in polluted soil or utilizing textile wastewater for watering system.

\section{REFERENCES}

Abbas, M.S., M. Akmal, Saif Ullaha, M.U. Hassan and S. Farooq. 2017. Effectiveness of zinc and gypsum application against cadmium toxicity and accumulation in wheat (Triticum aestivum L.). Commu. Soil Sci. Plant Anal. 48:1659-1668.

Abbas, T., M. Rizwan, S. Ali, M.Z. Rehman, M.F. Qayyum, F. Abbas, F. Hannan, J. Rinklebe and Y.S. Ok. 2017. Effect of biochar on cadmium bioavailability and uptake in wheat (Triticum aestivum L.) grown in a soil with aged contamination. Ecotoxicol. Environ. Saf. 140:3747.

Adams, M.L, F.J. Zhao, S.P. McGrath, F.A. Nicholson and B.J. Chambers. 2004. Predicting cadmium concentrations in wheat and barley grain using soil properties. J. Environ. Qual. 33:532-541.

Ahmet, A.E., H. E. Yildiz, S. Ercisli, F. M. Donmez and M. Turan. 2010. Effects of plant growth promoting bacteria (PGPB) on yield, growth and nutrient contents of organically grown strawberry. Sci. Hortic. 124:62-66.

Ajari, O., L.E.K. Tsado, J.A. Oladiran and E.A. Salako. 2003. Plant height and fruit yield of okra as affected by field application of fertilizer and organic matter in Bida, Nigeria. The Nigerian Agric. J.34:74-80.

Awodun, M.A. 2007. Effect of poultry manure on the growth, yield and nutrient content of fluted pumpkin (Telfaria occidentalis Hook F). Asian J. Agirc. Res. 1:67-73.

Ayers, R.S. and D.W. Westcot. 1985. Water Quality for Agriculture. FAO Irrigation and Drainage Paper 29, Rev. 1, U.N. Rome; pp.95-97.

Bashir, S., Q. Hussain, M.S. Rana, S. ur Rehman, S.A. Muhammad, M. Hassan, A. Rahman and A.R. Asif. 2017. Impact of biochar on organic and inorganic environmental pollutants and its mechanism: a review. J. Glob. Innov. Agric. Soc. Sci. 5:64-73.

Beesley, L., O.S. Inneh, G.J. Norton, E. Moreno-Jimenez, T. Pardo, R. Clemente and J. Dawson 2014. Assessing the influence of compost and biochar amendments on the mobility and toxicity of metals and arsenic in a naturally contaminated mine soil. Environ. Pollut. 186:195-202.

Brar, M.S., S.S. Malhi, A.P. Singh, C.L. Arora, and K.S. Gill. 2000. Sewage water irrigation effects on some potentially toxic trace elements in soil and potato plants in northwestern India. Can. J. Soil Sci. 80:465-471.

Brown, S., R. Chaney, J. Hallfrisch, J.A. Ryan and W.R. Berti. 2004. In situ soil treatments to reduce the phytoand bioavailability of lead, zinc, and cadmium. J. Environ. Qual. 33:522-531. 
Chang, Z.M. and X.H. Wu. 2005. Difference comparison of three alfalfa varieties resistant to cadmium pollution. Plant Cult. Sci. 22:20-23.

Clemente, R., D.J. Walker, T. Pardo, D. MartinezeFernandez and M.P. Bernal. 2012. The use of halophytic plant species and organic amendments for the remediation of a trace elements-contaminated soil under semi-arid conditions. J. Hazard Mater. 223:63-71.

Fagwalawa, L. D. and S.M. Yahaya. 2016. Effect organic manure on the growth and yield of Okra. Imperial J. Interdisc. Res. 2:2454-1362.

Foucault, Y., M.J. Durand, K. Tack, E. Schreck, F. Geret, T. Leveque, P. Pradere, S. Goxi and C. Gumat. 2013. Use of eco toxicity test and eco scores to improve the management of polluted soils: case of secondary lead smelter plant. J. Hazard Mater. 246:291-299.

Gadd, G.M. 2000. Bioremedial potential of microbial mechanisms of metal mobilization and immobilization. Curr. Opin. Biotechnol. 11:271-279.

Geeblen, W., D.C. Adriano, D. Van Der Lelie, M. Mench, R. Carleer, H. Clijsters and J. Vangronsveld. 2003. Selected bioavailability assays to test the efficacy of amendment-induced immobilization of lead in soil. Plant Soil 249:217-228.

Khan, M.A., M.R. Chattha, K. Farooq, M.A. Jawed, M. Farooq, M. Imran, M. Iftkhar and M.I. Kasana. 2015. Effect of farmyard manure levels and NPK applications on the pea plant growth, pod yield and quality. Life Sci. Int. J. 9:3178-3181.

Liang, X.F., J. Han, Y.M. Xu, Y.B. Sun, L. Wang and X. Tan. 2014. In situ field scale remediation of Cd polluted paddy soil using sepiolite and palygorskite. Geoderma. 235:9-18.

Liu, H.S., F.M. Li and H. Xu. 2004. Deficiency of water can enhance root respiration rate of drought-sensitive but not drought-tolerant spring wheat. Agric. Water Manag. 64:41-48.

Masarirambi, M.T., M.M. Hlawe, O.T. Oseni and T.E. Sibiya. 2010. Effects of organic fertilizers on growth, yield, quality and sensory evaluation of red lettuce (Lactuca sativa L.) 'Veneza Roxa'. Agric. Biol. J. North America 1:1319-1324.

Nagarajappa, D.P., S. Chavan and K.K. Gowda. 2017. Removal of heavy metals from textile mill wastewater by soil aquifer treatment system in conjunction with adsorbent. Int. Res. J. Engg. Technol. 4:2266-2268.

Ogunlela, V.B., M.T. Masarirambi and S.M. Makuza. 2005. Effect of cattle manure application on pod yield and yield indices of okra (Abelmoschus esculentus L. Moench) in semi-arid and subtropical environment. J. Food Agric. Environ. 3:5-15.

Okalebo, J. R., C. A. Palm, J. K. Lekasi, S. M. Nanolwa, C. O. Othieono and M. Waigwa. 2001. Use of organic and inorganic resources to increase maize yield in some Kenyan infertile soils. Moi University, Edoret, Kenya.

Premsekhar, M. and V. Rajashree. 2009. Influence of organic manure on growth, yield and quality of okra. Amer. Eurasian J. Sust. Agric. 31:6-8.

Puschenreiter, M., O. Horak, W. Friesl and W. Hartl. 2005. Low cost agricultural measures to reduce heavy metal transfer into the food chain- a review. J. Plant Soil Environ. 51:1-11.

Qayyum, M.F., M.Z. Rehman, S. Ali, M. Rizwan, A. Naeem, M.A. Maqsood, H. Khalid, J. Rinklebe and Y.S. Ok. 2017. Residual effects of monoammonium phosphate, gypsum and elemental sulfur on cadmium phytoavailability and translocation from soil to wheat in an effluent irrigated field. Chemosphere 174:515-523.

Rai, U. N., R.D. Tripathi, P. Vajpayee, V.N. Jha and M.B. Ali. 2002. Bioaccumulation of toxic metals $(\mathrm{Cr}, \mathrm{Cd}, \mathrm{Pb}$, and $\mathrm{Cu}$ ) by seeds of Euryale ferox Salisb. (Makhana). Chemosphere 46:267-272.

Rehman, M. Z., H. Khalid, F. Akmal, S. Ali, M. Rizwan, M.F. Qayyum, M. Iqbal, M.U. Khalid and M. Azhar. 2017. Effect of limestone, lignite and biochar applied alone and combined on cadmium uptake in wheat and rice under rotation in an effluent irrigated field. Environ. Pollut. 227:560-568.

Rizwan, M., S. Ali, T. Abbas, M.Z. Rehman, F. Hannan, C. Keller, M.I. Al-Wabel and Y.S. Ok. 2016. Cadmium minimization in wheat: a critical review. Ecotoxicol. Environ. Saf. 130:43-53.

Sabir, M., E.A. Waraich, K.R. Hakeem, M. Öztürk, H.R. Ahmad and M. Shahid. 2014. Phytoremediation: mechanisms and adaptations. Soil Remed. Plants. 85:85-105.

Sanwal, S.K., K. Lakminarayana, R.K. Yadav, N. Rai, D.S. Yaldav and B. Mousumi. 2007. Effect of organic manures on soil fertility, growth, physiology, yield and quality of turmeric. Ind. J. Hort. 644:444-449.

Shahid, M., M. Sabir, M.A. Ali and A. Ghafoor. 2014d. Effect of organic amendments on phytoavailability of nickel and growth of berseem (Trifolium alexandrinum) under nickel contaminated soil conditions. Chem. Speciat. Bioavailab. 26:37-42.

Sharma, A.D., M.S. Brar and S.S. Malhi. 2005. Critical toxic ranges of chromium in spinach plants and in soil. $\mathrm{J}$. Plant Nutr. 28:1-14.

Soltanpour, P.N. and S. Workman. 1979. Modification of the $\mathrm{NAHCO}_{3}$ DTPA soil test to omit carbon black. Commun. Soil Sci. Plant Anal. 10:1411-1420.

Sun, Y.B., G.H. Sun, Y.M. Xu, L. Wang, X.F. Liang and D.S. Lin. 2013. Assessment of sepiolite for immobilization of cadmium contaminated soils. Geoderma 193:149-155.

US Salinity Laboratory Staff. 1954. Diagnosis and improvement of saline and alkali soils. In: Agriculture 
Handbook, Vol. 60. United States Salinity Laboratory, USDA, Washington DC. 160.

Vajpayee, P., U.N. Rai, M.B. Ali, R.D. Tripathi, V. Yadav, S. Sinha and S.N. Singh. 2002. Chromium-induced physiologic changes in Vallisneria spiralis L. and its role in phytoremediation of tannery effluent, Bull. Environ. Contam. Toxicol. 67:246-256.

Venegas, A., A. Rigol and M. Vidal. 2015. Viability of organic wastes and biochars as amendments for the remediation of heavy metal-contaminated soils. Chemosphere 119:190-198.

Walker, D.J., R. Clemente and M.P. Bernal. 2004. Contrasting effects of manure and compost on soil $\mathrm{pH}$, heavy metal availability and growth of Chenopodium album L. in a soil contaminated by pyritic mine waste. Chemosphere 57:215-224.

Wang, F.L., W. Ouyang, F.F. Hao, C.Y. Lin and N.N. Song. 2014. In situ remediation of cadmium-polluted soil reusing four by-products individually and in combination. J. Soils Sediments 14:451-461.

Wong, S.C., X.D. Li, G. Zhang, S.H. Qi and Y.S. Min. 2002. Heavy metals in agricultural soils of the Peral River Delta, South China. Environ. Pollut. 119:33-44.

Worthington, V. 2001. Nutritional quality of organic versus conventional fruits, vegetables and grains. J. Altern. Complem. Med. 7:342-353.

Wuana, R.A. and F.E. Okieimen. 2011. Heavy metals in contaminated soils: A review of sources, chemistry, risks and best available strategies for remediation. Geo Environmental \& Climate Change Adaptation Research Centre; pp.20-21.

Yang, W.T., H. Zhou, J.F. Gu, B.H. Liao, P.Q. Peng and Q.R. Zeng. 2017. Effects of a combined amendment on $\mathrm{Pb}, \mathrm{Cd}$, and as availability and accumulation in rice planted in contaminated paddy soil. Soil Sedim. Contam. Int. J. 26:70-83. 